\title{
Peningkatan Pengetahuan dan Sikap Kepala Keluarga tentang Pengelolaan Sampah Melalui Pemberdayaan Keluarga di Kelurahan Tamansari Kota Bandung
}

\author{
Tati Ruhmawati $^{1}$, Mimin Karmini ${ }^{1}$, Dwi Tjahjani P. ${ }^{1}$ \\ ${ }^{1}$ Jurusan Kesehatan Lingkungan Poltekkes Kemenkes Bandung \\ Jalan Babakan Loa 10 A Gubungbatu Cimahi Utara, Indonesia \\ Info Artikel : Diterima Desember 2016 ; Disetujui Februari 2017 ; Publikasi April 2017
}

\begin{abstract}
ABSTRAK
Latar belakang: Sungai Cikapundung merupakan tempat dimana masyarakat banyak membuang sampah ke dalamnya. Pemberdayaan keluarga merupakan alternatif model yang diharapkan merubah pengetahuan dan sikap menuju keluarga yang lebih baik. Penelitian ini bertujuan untuk menganalisis pengetahuan dan sikap keluarga sebelum dan sesudah pemberdayaan pengelolaan sampah.

Metode: Penelitian ini merupakan penelitian eksperimen semu dengan rancangan "pre and post design." Intervensi yang dilakukan adalam pemberdayaan model keluarga mencakup konseling, pelatihan, dan pendampingan. Populasi penelitian ini adalah seluruh kepala keluarga atau wakilnya yang tinggal di sekitar aliran sungai Cikapundung di Rw 06 Kelurahan Tamansari Bandung Wetan. Pengambilan sampel diambil secara non random. Pengumpulan data dilakukan melalui wawancara dan observasi. Analisis ststistik untuk uji beda digunakan indepnden $\mathrm{T}$ test pada taraf signifikasi $5 \%$.

Hasil: Hasil penelitian ini menunjukkan bahwa sebanyak 82,6\% responden berumur tidak produktif; 56,5\% berpendidikan Sekolah Menengah Atas; 87\% tidak bekerja; 56,5\% berpenghasilan di bawah UMR; 100\% muslim, telah tinggal lebih dari satu tahun, sebagian besar mempunyai 4 anggota keluarga. Fasilitas pendukung pengelolaan sampah yang ada di lingkungan mereka adalah tempat pembuangan sampah sementara (TPS, motor angkut sampah, dan ada lembaga bank sampah. Setelah intervensi pemberdayaan, pengetahuan dan sikap mereka sangat baik masing-masing $78,3 \%$ dan $82,6 \%$. Hasil analisis statistik menunjukkan ada perbedaan pengetahuan dan sikap secara signifikan antara sebelum dan sesudah intervensi pemberdayaan keluarga $(p=0,001$ dan $\mathrm{p}=0,005)$.
\end{abstract}

Simpulan: Intervensi pemberdayaan mampu meningkatkan secara signifikan pengetahuan dan sikap keluarga dalam pengelolaan sampah.

Kata kunci: Pemberdayaan keluarga; pengetahuan dan sikap; pengelolaan sampah; Bandung.

\section{ABSTRACT}

Title: The Increasing of Knowledge and Attitudes of Family Head on Waste Management Through Family Empowerment in Tamansari Urban Village Bandung.

Background: Cikapundung river was deteriorated due to the behavior of people who throw garbage directly into the river. Empowerment is an alternative family model that is expected to change knowledge and attitudes towards a better family. This research aimed to analyze the knowledge and attitudes of families before and after the empowerment of waste management.

Method: Type of this research was quasi-experimental design with one group pre and post test design, which is a study design before and after the intervention using a control group without. The form of intervention is the empowerment model families which include counseling, training, and mentoring. The population in this study were all heads of families or representing in citizens association (RW) 06 Sub Tamansari Sub-District Bandung Wetan located around the river flow of Cikapudung river, while the sample is part of the head of household who 
are respondents, the sampling technique is non-random (accidental). The data collected by interview and observation. Data collector in the form of questionnaires, observation sheets. Analysis of the data by univariate and bivariate dependent $T$ test.

Result: The research results showed $82.6 \%$ of respondents age groups unproductive, $56.5 \%$ high school educated, $87 \%$ did not work, 56.5\% income below the minimum wage, 100\% Muslim, length of stay more than one year, $78.3 \%$ of domicile as wives, the number of family members $47.8 \%$ more than 4 people. Supporting infrastructure and facilities available in RW 06 in waste management is their shelter temporary garbage (TPS), the motor of garbage (Triseda), and the presence of garbage bank. Knowledge and attitude of the respondent after the intervention, including the excellent category with a percentage of $78.3 \%$ for the knowledge and attitude of $82.6 \%$. there are differences in knowledge and attitude of the respondent after the intervention with $p=0.001$ for knowledge and $p=0.005$ for the attitude.

Conclusion: There are significant difference between knowledge and attitudes before and after intervention.

Keywords: Family empowerment; knowledge and attitude; solid waste.

\section{PENDAHULUAN}

Air sungai merupakan salah satu sumber air yang banyak dimanfaatkan untuk memenuhi kebutuhan hidup manusia dan makhluk hidup lainnya. Sungai merupakan ekosistem yang sangat penting bagi manusia. Sungai menyediakan air bagi manusia baik untuk berbagai kegiatan seperti pertanian, industri maupun domestik. ${ }^{1}$ Namun sungai sudah banyak mengalami kualitas karena ulah manusia dengan banyaknya sampah dan limbah cair rumah tangga yang dibuang ke sungai. Sungai Cikapundung adalah salah satu sungai yang membelah Kota Bandung melewati sembilan kecamatan yang mencakup 13 kelurahan.

Sungai Cikapundung memiliki fungsi dan peran yang sangat penting bagi perkembangan Kota Bandung, karena sungai ini berfungsi sebagai sumber air baku bagi Kota Bandung. Kondisi pemukiman di daerah sekitar aliran Sungai Cikapundung Kelurahan Tamansari sangat padat. Permasalahan yang terjadi akibat dari adanya permukiman warga Kelurahan Tamansari di sekitar Sungai Cikapundung adalah pencemaran air sungai yang disebabkan oleh pembuangan sampah maupun limbah rumah tangga ke dalam sungai tersebut.

Hasil penelitian menunjukkan, kadar amonium Sungai Cikapundung 1,8 mg/l melebihi baku mutu 1,5 $\mathrm{mg} / \mathrm{l}^{2}$ Adanya amonium dalam air sungai dapat digunakan sebagai indikator air sungai tersebut telah tercemar. Penelitian lain menunjukan bahwa kondisi badan air Sungai Cikapundung di daerah sampling kelurahan Tamansari menuju hilir ujung Kota Bandung yaitu Kelurahan Cijagra sudah tercemar sedang. Status mutu air tersebut dikaitkan dengan insidensi penyakit diare, jumlah bakteri coliform yang terhitung lewat metode Jumlah Perkiraan Terdekat (JPT), khususnya nilai fekal coli berbanding lurus dengan nilai insidensi penyakit diare. $^{3}$

Pembangunan perkotaan tidak akan terlepas dari pengelolaan sampah yang ditimbulkan dari aktivitas perkotaan. Timbulan sampah kota menunjukan tren yang terus meningkat, sejalan dengan pertumbuhan penduduk, meningkatnya kegiatan pembangunan, dan perubahan pola kosumsi masyarakat. Hingga saat ini, penanganan sampah masih terfokus pada penanganan timbulan sampah. Upaya untuk mengurangi kuantitas sampah sebesar 20\% pada periode 2004-2009 belum menunjukan hasil yang signifikan, dikarenakan rendahnya kesadaran masyarakat dan pemerintah daerah dalam menerapkan reduce, reuse dan recycle (3R). ${ }^{4}$

Menurut data Kementerian Lingkungan Hidup (KLH) tahun 2008, setiap orang membuang sampah kurang lebih 800 gram/hari/orang. Sedangkan pemerintah baru mampu mengumpulkan dan mengangkut sampah sekitar $60-70 \%$ dari total jumlah sampah yang ada. Untuk mengatasi masalah tersebut, maka sampah haruslah dikelola dengan baik disertai upaya pemanfaatannya sehingga diharapkan mempunyai keuntungan berupa nilai tambah. Keberhasilan pengelolaan sampah pada lingkungan permukiman sangat dipengaruhi oleh peran serta masyarakat sebagai penghasil sampah. ${ }^{5}$

Wilayah RW 06 merupakan salah satu RW di Kelurahan Tamansari Kota Bandung. Jumlah penduduknya sebanyak 618 jiwa terdiri dari $196 \mathrm{KK}$. Berdasarkan hasil survei pendahuluan, masyarakat di wilayah RW 06 masih mempunyai kebiasaan membuang sampah ke sungai. Walaupun sebagian ada juga yang membuangnya ke tempat penampungan sampah sementara (TPS). Pemukiman yang padat serta tercemarnya air sungai menandakan kerusakan lingkungan Sungai Cikapundung oleh faktor manusia. Oleh karena itu perlu upaya perbaikan lingkungan di sekitar sungai tersebut dengan melibatkan masyarakat. Pemberdayaan keluarga adalah upaya untuk menciptakan/meningkatkan kualitas keluarga baik secara individu maupun kelompok dalam memecahkan berbagai persoalan terkait upaya peningkatan kualitas hidup, kemandirian dan kesejahteraan masyarakat. Kemandirian tersebut meliputi kemandirian berpikir, bertindak dan mengendalikan apa yang mereka lakukan. Kemandirian keluarga merupakan suatu kondisi yang dialami oleh keluarga yang ditandai dengan kemampuan memikirkan, memutuskan serta melakukan sesuatu yang dipandang tepat demi mencapai pemecahan masalah-masalah yang dihadapi dengan mempergunakan daya kemampuan yang dimiliki. Daya kemampuan yang dimaksud adalah 
kemampuan kognitif, konatif, psikomotorik dan afektif serta sumber daya lainnya yang bersifat fisik/material. Kemandirian keluarga dapat dicapai tentu memerlukan sebuah proses belajar. Masyarakat yang mengikuti proses belajar yang baik, secara bertahap akan memperoleh daya, kekuatan atau kemampuan yang bermanfaat dalam proses pengambilan keputusan secara mandiri. ${ }^{6}$ Salah satu upaya yang bisa dilakukan untuk memperbaiki lingkungan RW 06 di sekitar aliran sungai Cikapundung adalah melalui kegiatan pemberdayaan keluarga dengan alternatif model pemberdayaan keluarga yang sesuai dengan kekuatan yang ada di masyarakat sekitara liran sungai Cikapundung melalui penyuluhan, penyuluhan dengan pendampingan, penyuluhan, pelatihan dengan pendampingan. Hasil penelitian Surahman, menunjukkan bahwa ketepatan strategi penyuluhan berhubungan erat dengan karakteristik sasaran penyuluhan. ${ }^{7}$ Hasil penelitian lain menunjukkan bahwa komitmen masyarakat dalam mengelola sampah tumbuh dari kesadaran dan kekuatan masyarakat secara bertahap. Proses pembinaan dan pendampingan menambah kekuatan dan kinerja pengelolaan sampah di RW $14 .^{8}$

Tujuan penelitian ini adalah mengetahui gambaran umum dan karakteristik keluarga, sarana dan prasarana pendukung dalam pengelolaan sampah dan limbah cair serta diperolehnya model pemberdayaan keluarga dalam pengelolaan sampah dan limbah cair di RW 06 Kelurahan Taman Sari Kecamatan Bandung Wetan Kota Bandung.

\section{MATERI DAN METODE}

Penelitian ini akan menganalisis pemberdayaan keluarga dalam pengelolaan sampah di RW 06 Kelurahan Tamansari Kecamatan Bandung Wetan Kota Bandung. Metode yang akan dipergunakan adalah metode kualitatif dan kuantitatif. Metode kualitatif dimaksudkan untuk mendapatkan informasi tentang kekuatan sumberdaya manusia dan dukungan lingkungan. Sedangan metode kuantitatif dipergunakan untuk menganalisis pengaruh pemberdayaan keluarga terhadap perubahan pengetahuan dan sikap keluarga.

Penelitian ini termasuk penelitian eksperimen semu dengan desain one group pre and post test design. Variabel dalam penelitian meliputi variabel terikat dan variabel bebas (independent variable.). Variabel terikat meliputi pengetahuan dansikap. Variabel bebas yaitu model pemberdayaan keluarga berupa: penyuluhan, pelatihan dan pendampingan. Responden akan diukur pengetahuan dan sikapnya dalam mengelola sampah sebelum dan sesudah diberikan intervensi.

Populasi dalam penelitian ini adalah seluruh kepala keluarga (KK) atau yang mewakili di RW 06 Kelurahan Tamansari Kecamatan Bandung Wetan yang berada di sekitar aliran Sungai Cikapundung Kota Bandung, yaitu sebanyak 196 KK, sedangkan sampel adalah sebagian dari KK yang menjadi
populasi.Teknik pengumpulan data dilakukan dengan cara :

1. Melakukan identifikasi kekuatan pada keluarga dengan cara wawancara untuk mengetahui tingkat pendidikan, umur, pekerjaan, penghasilan, jumlah anggota keluarga, kebiasaan mengelola sampah melalui wawancara mendalam.

2. Melakukan identifikasi kekuatan pada lingkungan dengan cara mengobservasi apakah tersedia tempat pembuangan sampah sementara (TPS), ada petugas pengumpul sampah, ada gerobak sampah, melaluiwawancara mendalam,

3. Melakukan pre test untuk mengetahui pengetahuan dan sikap responden,

4. Melakukan intervensi kepada responden melalui pemberdayaan keluarga dengan menggunakan model penyuluhan, pelatihan, dan pendampingan. Responden akan diberikan intervensi pertama kali dengan model penyuluhan, kemudian dilakukan pelatihan. Setelah dilakukan penyuluhan dan pelatihan, baru dilakukan kunjungan ke rumahrumah responden untuk dilakukan pendampingan. Penyuluhan dilakukan dua kali, pelatihan dua kali, dan pendampingan dua kali. Yang melakukan penyuluhan, pelatihan, dan pendampingan adalah tim peneliti.

5. Melakukan post test untuk mengetahui pengetahuan dan sikap responden setelah dilakukan intervensi.

Data yang telah terkumpul diolah menggunakan software kemudian dilakukan analisis univariat untuk mendeskripsikan gambaran umum dan karakteristik responden. Selanjutnya analisis bivariat untuk melihat hubungan pengetahuan, sikap dan perilaku responden sebelum dan setelah diberikan penyuluhan, pelatihan, dan pendampingan, menggunakan uji $\mathrm{T}$ dependent.

\section{HASIL DAN PEMBAHASAN}

Penelitian ini dilakukan di Wilayah RW 06 Kelurahan Tamansari Kecamatan Bandung Wetan Kota Bandung selama bulan Juni sampai dengan bulan November 2016. Hasil penelitian tentang karakteristik responden dapat dilihat pada tabel 1.

Tabel 1. Distribusi frekuensi karakteristik responden

\begin{tabular}{lcc}
\hline \multicolumn{1}{c}{ Karakteristik } & $\mathrm{f}$ & $\%$ \\
\hline Umur: & & \\
- Produktif & 4 & 17,4 \\
- Tidak produktif & 19 & 82,6 \\
\hline Pendidikan: & & \\
- SD & 1 & 4,3 \\
- SMP & 5 & 21,7 \\
- SMA & 13 & 56,5 \\
- PT & 4 & 17,4 \\
\hline Penghasilan: & & \\
- Di bawah UMR & 13 & 56,5 \\
- Di atas UMR & 10 & 43,5 \\
\hline Lama Tinggal: & & \\
- $\geq 1$ tahun & 23 & 100,0 \\
- < 1 tahun & 0 & \\
\hline
\end{tabular}


Berdasarkan tabel 1 dapat dilihat bahwa 82,6\% responden berumur tidak produktif, dengan pendidikan $56,5 \%$ berpendidikan SMA; 56,5\% berpenghasilan di bawah UMR, dengan lama tinggal semuanya lebih dari satu tahun.

Berdasarkan tabel 2 dapat dilihat bahwa kategori pengetahuan responden sebelum dilakukan intervensi $(4,3 \%)$ termasuk kategori sangat tidak baik, setelah intervensi tidak ada lagi yang termasuk kategori sangat tidak baik. Sedang untuk kategori sikap responden sebelum dilakukan intervensi $(4,3 \%)$ termasuk kategori sangat tidak baik, setelah intervensi tidak ada lagi yang termasuk kategori sangat tidak baik.

Tabel 2. Distribusi frekuensi kategori pengetahuan responden sebelum dan sesudah dilakukan intervensi

\begin{tabular}{lcccc}
\hline \multirow{2}{*}{\multicolumn{1}{c}{ Variabel }} & \multicolumn{2}{c}{$\begin{array}{c}\text { Sebelum } \\
\text { intervensi }\end{array}$} & \multicolumn{2}{c}{$\begin{array}{c}\text { Sesudah } \\
\text { intervensi }\end{array}$} \\
\cline { 2 - 5 } & $\mathrm{f}$ & $\%$ & $\mathrm{~F}$ & $\%$ \\
\hline Pengetahuan: & & & & \\
Sangat baik & 9 & 39,1 & 18 & 78,3 \\
Baik & 9 & 39,1 & 5 & 21,7 \\
Tidak baik & 4 & 17,4 & 0 & 0 \\
Sangat tidak baik & 1 & 4,3 & 0 & 0 \\
$\quad$ Total & 23 & 100 & 23 & 100 \\
\hline Sikap: & & & & \\
Sangat baik & 9 & 39,1 & 19 & 82,6 \\
Baik & 8 & 34,8 & 4 & 17,4 \\
Tidak baik & 5 & 21,7 & 0 & 0,0 \\
Sangat tidak baik & 1 & 4,3 & 0 & 0,0 \\
$\quad$ Total & 23 & 100 & 23 & 100 \\
\hline
\end{tabular}

Hasil uji t dependent pada taraf signifikan 5\%, untuk menguji perbedaan pengetahuan responden sebelum dan sesudah dilakukan intervensi, diperoleh nilai $\mathrm{p}=0,001$, dimana nilai $\mathrm{p}$ lebih kecil dari $\alpha(0,05)$. Hasil uji t dependent pada taraf signifikan 5\%, untuk menguji perbedaan sikap responden sebelum dan sesudah dilakukan intervensi diperoleh nilai $p=0,005$, dimana nilai $\mathrm{p}$ lebih kecil dari $\alpha(0,05)$.

Berdasarkan hasil pengumpulan data, karakteristik responden $82,6 \%$ umurnya termasuk dalam kelompok tidak produktif dengan penghasilan $56,5 \%$ di bawah upah minimum regional (UMR). Tingkat pendidikannya $56,5 \%$ lulusan sekolah menengah atas (SMA), oleh karena itu pada umumnya mereka mengetahui dan sikap mereka juga menyadari bahwa sampah yang tidak dikelola akan menimbulkan masalah baik terhadap kesehatan maupun lingkungan. Namun karena kondisi ekonomi keluarga dan kondisi sarana prasarana yang kurang mendukung, seolah-olah menjadi tidak berdaya untuk merubah kebiasaan buruk dalam pengelolaan sampah di wilayah tersebut. Walaupun kondisi lingkungan permukiman dan pengelolaan sampah belum baik, mereka tetap nyaman tinggal di wilayah tersebut karena wilayah RW 06 ini cukup strategis. Kebiasaan berperilaku membuangan sampah ke Sungai Cikapundung dianggap hal biasa.
Berdasarkan wawancara dengan Bapak Mulyadi, Ketua RW 06, masyarakat yang tinggal di wilayahnya kebanyakan pendatang. Rasa peduli dan gotong royong sudah berkurang, mereka sibuk dengan rutinitasnya sebagai mahasiswa maupun karyawan dan pedagang, sehingga tidak peduli dengan kondisi lingkungan yang ada.

Banyak faktor yang menyebabkan pengelolaan sampah di Wilayah RW 06 Kelurahan Taman Sari Kecamatan Bandung Wetan Kota Bandung ini belum berjalan sebagaimana mestinya. Sarana dan prasarana yang tersedia untuk kegiatan pengelolaan sampah belum mendukung, disamping rendahnya dukungan partisipasi masyarakat. Dengan kondisi tersebut di atas, maka perlu adanya upaya pemberdayaan masyarakat sehingga masyarakat dapat menyelesaikan masalahnya secara mandiri.

Strategi pembangunan kesehatan seperti tertuang dalam RPJPN Bidang Kesehatan tahun 2005-2025 antara lain menyebutkan tentang pemberdayaan masyarakat. Peran masyarakat dalam pembangunan kesehatan semakin penting. Masalah kesehatan perlu diatasi oleh masyarakat sendiri dan pemerintah. Keberhasilan pembangunan kesehatan, penyelenggaraan berbagai upaya kesehatan harus berangkat dari masalah dan potensi spesifik daerah termasuk di dalamnya sosial dan budaya setempat. Sistem Kesehatan Nasional menyatakan bahwa pemberdayaan masyarakat bertujuan meningkatkan kemampuan masyarakat untuk berperilaku sehat, mampu mengatasi masalah kesehatan secara mandiri, berperan aktif dalam setiap pembangunan kesehatan, serta dapat menjadi penggerak dalam mewujudkan pembangunan berwawasan kesehatan. Untuk itu potensi yang dimiliki masyarakat perlu digerakkan.

Selain masyarakat, keluarga juga sebagai bagian terkecil masyarakat yang bisa diberdayakan. Pemberdayaan keluarga dapat dipandang sebagai suatu proses memandirikan klien dalam mengontrol status kesehatannya. Pengertian lain tentang pemberdayaan adalah memampukan orang lain melalui proses transfer termasuk di dalamnya transfer kekuatan/power, otoritas, pilihan dan perijinan sehingga mampu menentukan pilihan dan membuat keputusan dalam mengontrol hidupnya. ${ }^{9} \quad$ Pemberdayaan keluarga memiliki makna bagaimana keluarga memampukan dirinya sendiri dengan difasilitasi orang lain untuk meningkatkan atau mengontrol status kesehatan keluarga.

Hasil analisis deskriptif diperoleh nilai rerata pengetahuan sebelum dan sesudah intervensi masingmasing 11,09 dan 13,78. Sedang untuk nilai rerata sikap sebelum dan sesudah intervensi masing-masing 27,39 dan 32,87. Berdasarkan hasil uji t dependent, terdapat perbedaan pengetahuan yang bermakna antara sebelum dan setelah dilakukan intervensi dengan $p$ value $=0,001$. Seperti telah dijelaskan di atas bahwa intervensi yang dilakukan adalah penyuluhan, pelatihan, dan pendampingan. Penyuluhan secara klasikal dilakukan dua kali, materi penyuluhan adalah 
tentang pengelolaan sampah. Materi pengelolaan sampah meliputi konsep reuse, reduce, dan recyle (3R). Serta dampak yang terjadi baik terhadap lingkungan maupun terhadap kesehatan apabila sampah tidak dikelola dengan baik. Kegiatan pelatihan dilakukan dua kali, materi yang diberikan adalah tentang cara daur ulang sampah plastik dan pembuatan kompos skala rumah tangga menggunakan alat komposter sederhana. Sedangkan kegiatan pendampingan berupa penyuluhan dengan metode door to door, dikunjungi ke rumah responden untuk mendampingi mereka berkaitan dengan pengelolaan sampah. Apabila dilihat dari tingkat pengetahuan responden, terdapat peningkatan setelah dilakukan intervensi. Sebelum dilakukan intervensi, kategori pengetahuan mereka masih ada yang sangat tidak baik $(4,3 \%)$, setelah intervensi kategori pengetahuan mereka sudah meningkat, tidak ditemukan lagi yang termasuk kategori sangat tidak baik. Demikian pula kategori sikap responden terjadi peningkatan. Berdasarkan hasil uji $\mathrm{t}$ dependent, terdapat perbedaan sikap yang bermakna antara sebelum dan setelah dilakukan intervensi dengan $p$-value $=0,005$. Hasil penelitian yang dilakukan oleh Surahman, menunjukkan hasil bahwa ketepatan strategi penyuluhan berhubungan erat dengan karakteristik sasaran penyuluhan. ${ }^{7}$ Hasil penelitian lain menunjukkan bahwa komitmen masyarakat dalam mengelola sampah tumbuh dari kesadaran dan kekuatan masyarakat secara bertahap. Proses pembinaan dan pedampingan menambah kekuatan dan kinerja pengelolaan sampah. ${ }^{8}$

Berdasarkan hasil pendampingan, setelah dilakukan penyuluhan dan pelatihan, sebagian responden sudah mencoba mempraktekkan ilmu yang sudah diperolehnya dari kegiatan penyuluhan dan pelatihan. Bahkan ada juga responden yang menjadi motivator bagi responden yang lainnya dengan mengajak dan mengajari ilmu yang telah diperolehnya. Hal ini menunjukkan bahwa ketika masyarakat ditingkatkan kemampuannya diharapkan mampu mengatasi masalahnya khususnya masalah pengelolaan sampah secara mandiri, berperan aktif dalam setiap pembangunan, serta dapat menjadi penggerak dalam mewujudkan pembangunan. Upaya pemberdayaan rakyat harus dilakukan melalui tiga cara. Pertama, menciptakan suasana dan iklim yang memungkinkan potensi masyarakat untuk berkembang. Kondisi ini berdasarkan asumsi bahwa setiap individu dan masyarakat memiliki potensi yang dapat dikembangkan. Hakikat kemandirian dan dan keberdayaanrakyat adalah keyakinan bahwa rakyat memiliki potensi untuk mengorganisasikandirinya sendiri dan potensi kemandirian individu perlu diberdayakan. Prosespemberdayaan rakyat berakar kuat pada proses kemandirian setiapindividu yang kemudian meluas ke keluarga, serta kelompok masyarakat baik ditingkat lokal maupun nasional. Kedua, memperkuat potensi atau daya yangdimiliki oleh rakyat dengan menerapkan langkah-langkah nyata, menampungberbagai masukan, menyediakan prasarana dan sarana, baik fisik maupun sosialyang dapat diakses oleh masyarakat lapisan bawah. Ketiga, memberdayakanrakyat dalam arti melindungi yang lemah dan membela kepentingan masyarakatlemah. Dalam proses pemberdayaan harus dicegah jangan sampai yang lemahmakin terpinggirkan dalam menghadapi yang kuat. ${ }^{10}$

Seperti telah dijelaskan di atas, bahwa pengelolaan sampah di wilayah RW 06 belum berjalan dengan baik. Pengelolaan sampah belum dikelola dengan baik, responden ada yang membuang sampahnya ke TPS, ada yang diangkut oleh motor sampah (Triseda), ada juga yang membuangnya ke sungai. Sampah rumah tangga merupakan penyumbang sampah terbesar. Timbunan sampah yang terus menumpuk akan berakibat buruk bagi kesehatan lingkungan serta menimbulkan berbagai penyakit. Jumlah penduduk Indonesia yang besar dengan tingkat pertumbuhan yang tinggi mengakibatkan bertambahnya volume sampah. Selain itu, pola konsumsi masyarakat memberikan kontribusi dalam menimbulkan jenis sampah yang semakin beragam, antara lain, sampah kemasan yang berbahaya serta sulit diurai secara alamiah.

Sebagian besar masyarakat masih memandang sampah sebagai barang sisa yang tidak berguna, menjijikan dan tidak bisa dimanfaatkan kembali. Masyarakat masih beranggapan bahwa pengelolaan sampah sepenuhnya tanggung jawab pemerintah. Mereka masih berpikir, tanggung jawab mereka cukup menyimpan sampah pada tempatnya, proses selanjutnya merupakan tanggung jawab pemerintah. Kondisi saat ini, tempat pembuangan akhir sampah (TPA) yang tersedia tidak akan bisa menampung sampah yang terus menerus dihasilkan masyarakat jika masyarakat tidak mulai bertindak untuk mengurangi sampah yang dihasilkan.

Saat ini hampir seluruh pengelolaan sampah berakhir di TPA sehingga menyebabkan beban TPA menjadi sangat berat, selain diperlukannya lahan yang cukup luas, juga fasilitas perlindungan lingkungan yang sangat mahal. Hal tersebut disebabkan karena belum dilakukannya upaya pengurangan volume sampah secara sungguh-sungguh sejak dari sumber, termasuk pemisahan sampah B3 (Bahan Beracun Berbahaya) rumah tangga. Peningkatan laju timbulan sampah perkotaan yang tidak diikuti dengan ketersediaan prasarana dan sarana persampahan yang memadai, berdampak pada pencemaran lingkungan yang selalu meningkat dari tahun ke tahun. Dengan selalu mengandalkan pola kumpul-angkut-buang, maka beban pencemaran akan selalu menumpuk di lokasi TPA. Meningkatnya laju pertumbuhan industri dan konsumsi masyarakat secara umum berdampak pula pada perubahan komposisi dan karakteristik sampah yang dihasilkan terutama semakin banyaknya penggunaan plastik, kertas, produk-produk kemasan dan komponen bahan yang mengandung B3 serta non biodegradable. Pengurangan volume sampah 
merupakan suatu keharusan untuk menyikapi kondisi tersebut di atas.

Paradigma pengelolaan sampah yang bertumpu pada pendekatan akhir (yaitu sampah dikumpulkan, diangkut, dan dibuang ke tempat pemrosesan akhir sampah) sudah saatnya ditinggalkan dan diganti dengan paradigma baru pengelolaan sampah. Paradigma baru memandang sampah sebagai sumber daya yang mempunyai nilai ekonomi dan dapat dimanfaatkan, misalnya, untuk energi, kompos, pupuk ataupun untuk bahan baku industri. Pengelolaan sampah dilakukan dengan pendekatan yang komprehensif dari hulu, sejak sebelum dihasilkan suatu produk yang berpotensi menjadi sampah, sampai ke hilir, yaitu pada fase produk sudah digunakan sehingga menjadi sampah, yang kemudian dikembalikan ke media lingkungan secara aman. Pengelolaan sampah dengan paradigma baru tersebut dilakukan dengan kegiatan pengurangan dan penanganan sampah. Pengurangan sampah meliputi kegiatan pembatasan, penggunaan kembali, dan pendauran ulang, sedangkan kegiatan penanganan sampah meliputi pemilahan, pengumpulan, pengangkutan, pengolahan, dan pemrosesan akhir. ${ }^{11}$

Suatu pendekatan atau paradigma baru harus dipahami dan diikuti yaitu bahwa sampah dapat dikurangi, digunakan kembali dan atau didaur ulang; atau yang sering dikenal dengan istilah reduce, reuse, recycle (3R). Konsep 3R bukan sesuatu yang baru karena sudah banyak dilakukan oleh negara maju dan berhasil meningkatkan efisiensi pengelolaan yang signifikan. Dengan mengurangi sampah sejak dari sumbernya maka beban pengelolaan sampah dapat dikurangi dan anggaran serta fasilitas akan semakin efisien. Beban pencemaran dapat dikurangi dan lebih jauh lagi dapat turut menjaga kelestarian alam dan lingkungan.

Bank Sampah adalah salah satu strategi penerapan 3R dalam pengelolaan sampah di tingkat masyarakat. Pelaksanaan bank sampah pada prinsipnya adalah satu rekayasa sosial (Social Engineering) untuk mengajak masyarakat memilah sampah. Mengajak masyarakat memilah sampah adalah pekerjaan yang sangat sulit karena menyangkut kebiasaan, budaya dan ketidakpedulian masyarakat yang rendah. Solusi inovatif untuk "memaksa"e masyarakat memilah sampah adalah bank sampah dengan menyamakan sampah serupa uang yang dapat ditabung. ${ }^{12}$

Keberadaan bank sampah di Wilayah RW 06 belum berfungsi secara maksimal. Belum semua warga menjadi nasabah. Pada awal berdirinya jumlah nasabah lebih dari 50 orang, akan tetapi seiring berjalannya waktu jumlahnya terus menurun. Keluhan yang dirasakan adalah karena bank sampah ini hanya buka satu minggu sekali tiap hari Sabtu, sehingga sampah yang sudah dipilah oleh responden di masing-masing rumah menjadi menumpuk dan memakan tempat. Hal ini tidak akan terjadi apabila pengelola Bank Sampah ini bisa melayani nasabah setiap hari atau minimal dua kali dalam seminggu. Disamping itu sosialisasi tentang bank sampah ini harus terus dilakukan agar masyarakat termotivasi untuk berpartisipasi menjadi nasabah yang aktif. Hasil penelitian menunjukkan hasil bahwa ada hubungan antara tingkat pendidikan dan pendapatan dengan pengelolaan bank sampah. Kalau melihat karakteristik responden, masih ada yang berpendidikan sekolah dasar (SD), serta penghasilannya masih di bawah upah mimimum regional (UMR). ${ }^{13}$ Hasil penelitian lain menunjukkan bahwa dengan adanya program bank sampah, membantu pemerintah dalam mengurangi volume sampah dan sudah memberikan dampak yang baik untuk masyarakat dan lingkungan. ${ }^{14}$

\section{SIMPULAN}

Sebanyak $82,6 \%$ responden termasuk kelompok umur tidak produktif; 56,5\% berpendidikan SMA; 87 $\%$ tidak bekerja; 56,5\% penghasilannya di bawah UMR; 100\% beragama Islam, lama tinggal lebih dari satu tahun; 78,3\% berkedudukan sebagai istri, jumlah anggota keluarga 47,8\% lebih dari 4 orang. Sarana dan prasarana pendukung yang tersedia di Wilayah RW 06 dalam pengelolaan limbah adalah adanya tempat penampungan sampah sementara (TPS), motor pengangkut sampah (Triseda), dan terdapatnya bank sampah. Terdapat perbedaan yang signifikan antara pengetahuan, sikap dan perilaku responden sebelum dan sesudah dilakukan intervensi.

\section{DAFTAR PUSTAKA}

1. Siahaan R, Indawan A, Soedharma D, Prasetyo LB. Kualitas Air Sungai Cisadane, Jawa Barat- Banten. Jurnal Ilmiah Sains 2011, Vol. 11, hal. 268-273.

2. Bethy, Matahelumual C. Kajian Kualitas Air Sungai Sebagai Sumber Air Baku PDAM (Sungai Citarum dan Cikapundung). Buletin Geologi Tata Lingkungan, April 2010, Vol. 20 No. 1.

3. Badiamurti,Garneta R, Setiani, Barti M. Korelasi Kualitas Air dan Insiden Penyakit Diare Berdasarkan Keberadaan Bakteri Coliform di Sungai Cikapundung. Program Studi Teknik Lingkungan, Fakutas Teknik Sipil dan Lingkungan : ITB. 2011.

4. Thrihadiningrum, Yulinah. MDGs Sebentar Lagi Sanggupkah Kita Menghapus Kemiskinan di Dunia. Jakarta: PT Gramedia,2010.

5. Aryenti. Peningkatan Partisipasi Masyarakat dalam Pengelolaan Sampah dengan Cara Reduce, Reuse, Recycle (3R) di Lingkungan Permukiman Ditinjau dari Segi Sosial Ekonomi Masyarakat. Jurnal Permukiman, Agustus 2010, Vol. 6 No. 2, hal. 7583.

6. Widjajanti, Kesi. PemberdayaanMasyarakat. Jurnal Ekonomi Pembangunan, Juni 2010, Vol. 12 No.1.

7. Surahman, Endan, Hermawan, Yoni. Pengaruh Strategi Penyuluhan dan Motivasi Pemeliharaan Kesehatan Lingkungan terhadap Pengetahuan Ibu Rumah Tangga tentang Sampah. Jurnal Bumi Lestari, Agustus 2011, Vol. II No. 2, hal. 360-370.

8. Iman, Halwatul, Kustiwan, Iwan. Keberlanjutan Pengelolaan Sampah Berbasis Masyarakat di 
Kelurahan Tamansari Kota Bandung. Jurnal Perencanaan Wilayah dan Kota B SAPPK V2N2 , 2011, hal 283-290.

9. Rodwell CM. An analysis of the Concept of Empowerment. J. Adv. Nurs, 1996, Vol 23 No. 2, p. 305-313.

10. Kartasasmita, Ginanjar. Pemberdayaan Masyarakat: Konsep Pembangunan yang Berakar pada Masyarakat. Jakarta : Bappenas, 1996.

11. Departemen Hukum Dan Hak Asasi Manusia RI. Undang-Undang Republik Indonesia Nomor 18 tahun 2008 tentang Pengelolaan Sampah. Jakarta, 2008.
12. Badan Lingkungan Hidup. Merubah Sampah Menjadi Uang Melalui Bank Sampah. Palangka Raya, 2012.

13. Sofiana, Maria. Keterkaitan Pengelolaan Bank Sampah dengan Tingkat Pendidikan dan Pendapatan Masyarakat Perumahan Muria Indah di Desa Gondangmanis Kecamatan Bae Kudus. Edu Geography 2015, Vol. 3 No. 7.

14. Mutiara, Saputri M. Evaluasi Dampak Kebijakan Pemerintah Daerah dalam Pengelolaan Sampah Melalui Program Bank Sampah. Jurnal Administrasi Publik (JAP), Vol. 3 No. 11, hal 18041808. 